\title{
DIFFERING UNJUST ENRICHMENT AND DAMAGES IN THEORY AND PRACTICE UNDER MACEDONIAN LAW
}

\author{
Marija AMPOVSKA \\ E-Mail: marija.ampovska@ugd.edu.mk \\ Associate professor at the Faculty of Law \\ Goce Delchev University in Shtip, R.N.Macedonia
}

\begin{abstract}
Two different relationships regulated by the law of obligations will be subject of analyses in this paper: unjust enrichment and civil liability. In the Republic of North Macedonia, they are distinguished from one another in the legal theory as well as in legislation, and there are different prerequisites for the rise of the obligations as well as for the claims in cases of court protection of subjective rights. The boundary between them is not so clearly drawn with respect to the prerequisites for the claim or the legal consequences. There is a fluid transition between the law on unjust enrichment and law on damages and overlap between them. The papers aim to detect those similarities, as well as to list the differences between the unjust enrichment and the damages in a way that will be useful for both legal theory and practice in Macedonian law. Enrichment of this paper will be the research conducted in the court practice in eastern Macedonian region in order to establish the current legal practice and problems with regard to these two obligations.
\end{abstract}

Key words: unjust enrichment, tort, liability, compensation of damage, claim.

1. Introduction on unjust enrichment and damages

In common law systems, historically, the prime impetus for the development of unjust enrichment has been to bring together various instances of restitutionary liability that common law had assigned to different compartments. (Weinrib, 2016) In the conventional view there is a qualitative difference between the 
unjust enrichment and the tort liability for damages, as unjust enrichment gives rise to so called restitutionary duties and torts give rise to compensatory duties (Smith, 2008, p. 12). Restitutionary duties are duties simply intended to cure a problem, to do justice. They have a remedial aim and there is no need to balance the defendant's and claimant's interests at this stage. On the other hand, compensatory duties are duties to remedy the consequences of wrongs (Smith, 2008, p. 19). It is widely excepted in theory that the restitutionary duties and the compensatory duties are closely related and that they share a remedial aim as well as a foundation in the principle of corrective justice. (Weinrib, 2016, p. 140) It is also well recognized in legal doctrine that the boundary between claims for unjust enrichment and claims for damages is not clearly drawn either with respect to the prerequisites for the claim or the legal consequences. (Koziol, 2012, p. 34) On the other hand, the definition of the unjust enrichment and the right to damages as two separate obligations has been clearly drawn in Roman law and all its receptors. Both obligations are based on a fundamental respect for each person's rights when it comes to relationship between private individuals and the need to protect their status quo. (Zimmermann, 1995, p. 403) But, there is significant difference in what is considered to be the moral foundation or the basic principle for the obligation. The moral foundation of the law of delicts in the Roman law is the following precept of natural law: "(I.) Ut ne quis alterum laedat, utque (II.) si quod damnum alteri dederit, id reparet", which stands for the obligation not to inflict damage to other, or the obligation to compensate it (repair it) will arise. The principle for unjust enrichment is expressed differently providing that it cannot be tolerated that one person becomes richer at the expense of another, as shown with the roman maxima: 'Nam hoc natura aequum est neminem cum alterius detrimento fieri locupletiorem"”. (Zimmermann, 1995, pp. 403-404)

2. General overview of the unjust enrichment and damages regulation in Macedonian law

Following the Roman law legacy, as well as incorporating it in the former and present Macedonian civil law, there is no doubt in theory nor in legislation that unjust enrichment and damages are two different obligations. Although the Macedonian legal system has left the specific divisions of obligations from the Roman law (the two-part, four-part and five-part division), the distinction of these obligations as separate is still present in the chosen approach for anticipation and legal regulation of the obligations. (Galev \& Anastasovska, 2008, p. 155). This approach was introduced in the Law on Obligations adopted in the former Socialist Federal Republic of Yugoslavia, and after the breakup of Yugoslavia it was introduced into the national laws of the independent republics, among them also in Republic of Macedonia. Today, the Law on 
Obligations in the Republic of North Macedonia ${ }^{1}$ (further in the text referred to as Law on Obligations) regulates five types of obligations: contracts, damages, unjust enrichment, management without mandate (negotiorum gestio) and unilateral statements of will (such as publicly promising reward and securities). (Galev \& Anastasovska, 2008, p. 155)

The present regulation of obligations provides that no one can enrich himself unjustly at the expense of third-party goods. The Law on Obligations provides that "...where a portion of a person's assets is transferred in any manner to the assets of another person and such a transfer is not based on a legal transaction, decision of a court or another competent authority or law, the acquirer shall return that portion of the assets, or if this is not possible, compensate for the value of the benefit conferred. Transfer of assets shall also imply benefit conferred by the performed act. The liability to return or compensate for the value shall occur when something is received on the basis which has not been realised or which has subsequently been suspended." ${ }^{2}$ In comparative legal theory it is recognized that the enrichment at the expense of another refers to the transfer of value, while the unjustness refers to the non-donative terms on which the plaintiff has given and the defendant has accepted this transferred value. (Weinrib, 2016, p. 35) The extent of the recourse is determined in article 203 from the Law on Obligations, which states that besides the object of return, the acquirer (the enriched person) that acted in bad faith is obligated to return the fruits and to repay the default interest, as of the date of acquisition, and otherwise, as of the date of submitting the claim. Regarding the compensation for the costs, the person enriched shall have a right to compensation for necessary and useful costs, but if he has acted in bad faith, he shall be entitled only to a compensation for necessary costs. ${ }^{3}$ In theory this provision is explained as a continuing effect of a right that manifests itself through the claim to the advantage gained in contravention of the lawful allocation (Koziol, 2012, p. 33).

Apart from the general provisions regarding the unjust enrichment, the Law on Obligations contains two specific rules on unjust enrichment by interference, which is translatable as claim for use. According to the first provision:" Should someone use his own or another person's object for the benefit of a third person, and the rules of doing business without an order (negotiorum gestio) do not apply, the third person is liable to restitute such object, or should this be

\footnotetext{
${ }^{1}$ Official Gazette of Republic of Macedonia No.18/01, 04/2002, 05/2003, 84/2008, $81 / 2009,161 / 2009,23 / 2013,123 / 2013$. The translation of this provision as well as all the other provisions used in this paper was provided by the author.

2 Article 199, Law on Obligations.

${ }^{3}$ Article 204, Law on Obligations.
} 
impossible, to indemnify its value."4 As noted, the disgorgement of profit gained by deliberate interference with third part rights may only be obtained under the law on unjust enrichment or at the most by invoking the concept of negotiorum gestio. (Koziol, 2012, p. 49) In this case unjust enrichment serves as an additional legal institute that applies when there is no place for negotiorum gestio.

The second provision refers to the case of the use of another person's object for one's own benefit. ${ }^{5}$ According to this provision where a person has used another person's object for his own benefit, the owner may, irrespective of a right to a compensation for damage, or in its absence, request compensation from the former for the benefit conferred from use of the object.

On the other hand, in Chapter 2 of the Law on Obligations, titled "Causing damage", regulates the second type of obligations. This chapter introduces a few sections that regulate the basic principles of Tort law, the general and specific prerequisites for raising the obligation and the liability for damages, as well as the specific types of liability regulated with this law. The basis of liability is set in Article 141 as follows: "A party causing damage to another party, with the presence of fault, is obliged to indemnify it. For damage due to objects or activities that increase the risk of damaging the environment, the liability is established regardless of fault. The law also provides for liability in other cases of damage regardless of fault." If we turn the focus on the general prerequisites for raising the liability, as defined in theory, we note three requirements: the presence of damage, the presence of a wrongful act that caused the damage and the existence of causation between them. (Ampovska, Отштетно право [Tort law], 2020, стр. 23-25). Compared with the unjust enrichment, we are facing three different prerequisites. The prerequisites that, based on the above-mentioned provisions, are defined by the theory of raising claims for unjust enrichment are the following (Ampovska, Отштетно право [Tort law], 2020, p. 51):

- A person's asset has increased

- Another person's asset has decreased and there is correlation between the increase and decrease

- There is no legal basis (titulus) for the transfer of assets

As a fourth prerequisite for raising claims of unjust enrichment, introduced into the legal doctrine, we encounter the following: the activity that leads to the transfer of assets is not considered to be a wrongful activity (delict) because, in cases like this, liability for damages should raise. (Antic, 2009, p. 535)

\footnotetext{
${ }^{4}$ Article 206, Law on Obligations.

${ }^{5}$ Article 208, Law on Obligations.
} 
3. Overlap and differing unjust enrichment and damages in the comparative legal doctrine

Having in mind these provisions, as well as the prerequisites as defined in theory for raising claims a certain obligation, there is no doubt that the overlap between the claim for unjust enrichment and the claim for damages can easily occur. Moreover, it is the dominant opinion of the scholars on the territory of the former Yugoslav states ${ }^{6}$ that the claim for unjust enrichment is necessarily a supplement to the claim for damage and that the plaintiff should have the possibility to choose (Radisic, 2018, p. 352). The claim for unjust enrichment has meaning and practical value only in cases where the lawful allocation of goods can be accomplished through natural or monetary restitution, but not in the cases where lost gain, future damage or indirect damage has also occurred (Galev \& Anastasovska, 2008, p. 656). The protection under the law of unjust enrichment can thus be applied in cases when the law of damages cannot be drawn due to the lack of any disadvantage suffered. On the other hand, it is recognised today that claims for unjust enrichment do not require any damage on the part of the person at whose expense the enrichment was gained (Koziol, 2012, p. 34).

In the case of claim for unjust enrichment and claim for damage there is a relationship based on competition. This means that the compensation in any particular case is achievable only by one ground and accumulation of the two claims for one case is not allowed (Pajtic, Radovanovic, \& Dudash, 2018, p. 612). Although one should bear in mind that there are possible exceptions especially in the case when the plaintiff has chosen the claim for unjust enrichment to claim the return of the object or item, but there has also been lost gain (lucrum cessans) that could not be reimbursed with this claim, but can be reimbursed with a new claim, claim for damages, based on the provisions for liability (Radisic, 2018, p. 351). From a practical point of view, it is more affordable and effective for the plaintiff to use the claim for damages at the beginning, thus avoiding two litigations. But, what also needs to be considered is that in some of the cases, the plaintiff will be forced to use the claim for unjust enrichment if at that time he cannot prove fault or equivalent grounds for liability to this party (for example, a special risk posed by something within his sphere of responsibility), or when the defendant is a minor who cannot be held liable under the law or when the claim for damage has been prescribed (Radisic, 2018, p. 351). Regarding the institute prescription under Macedonian law, it is notable that different prescription periods are provided for the two claims. It is provided that the claim for compensation of damage shall be prescribed within three years of the time the injured party became aware of the damage or the

\footnotetext{
${ }^{6}$ Bosnia, Macedonia, Slovenia, Serbia, Croatia and Montenegro.
} 
person causing the damage, and that in any case, such claim shall be prescribed within five years of the moment the damage has been caused. On the other hand, a claim for compensation of damage caused by breaching a contractual obligation shall be prescribed within the period stipulated for prescription of such obligation. ${ }^{7}$ Also, under the Macedonian law no specific prescription period is provided for the claims for unjust enrichment, and in this case the general prescription period of five years ${ }^{8}$ is applicable (Cavdar \& Cavdar, 2008, стр. 421).

Another specific characteristic that marks the relationship in terms of overlap between the unjust enrichment and the liability for damages is the possible transition from liability for unjust enrichment to liability for damages. For example, "the liability of an owner who knows of the duty to return something due to deficiencies in a commercial transaction and thus knows of the seller's claim with respect to unjust enrichment and carelessly destroys the item" (Koziol, 2012, p. 35), as case where the unjust enrichment has been transferred to liability for damages.

Another field where unjust enrichment and liability for damages meet is the compensation for damage in the event of physical injury, health impairment or death. Article 205 from the Law of obligations clearly states that the recourse relating to unjustly paid amounts for the compensation for damage, both pecuniary and non-pecuniary, in the event of physical injury, health impairment or death may not be requested, if the payment has been made in good faith to the person enriched. It is recognised in theory and court practice that, in this case, the person that made the payments may claim compensation from the person that is obligated to pay the amounts. (Cavdar \& Cavdar, 2008, p. 418)

Finally, certain academics point out that unjust enrichment and tort law should not be treated as independent or opposed types of obligations and that unjust enrichment should not be misunderstood as a distinctive legal category; rather, it is a reason for liability that is functionally and structurally comparable with concepts such as fault or individual responsibility which apply throughout the legal system. (Jansen, 2010, p. 16)

\footnotetext{
${ }^{7}$ Article 365, Law on Obligations

${ }^{8}$ Article 360 of the Law of Obligations states:"The period for prescription of claims shall be five years, unless otherwise provided by law."
} 
4. Differing unjust enrichment and damages through the litigation procedure regulation

In the litigation procedure as a cognitive procedure that is based on the principle of disposition, it is crucial to determine not only on what the court decision is based, but also what is the court litigating. In theory this is the definition for the institute that can be found as petition or subject of the dispute. But the determination of the subject of the dispute is one of the central and the most contentious questions in the litigation procedure. (Јакшић, 2009, стр. 274)

In the civil procedure the frame of the claim is determined by the legal grounds of the claim. The parties shall be obliged to state all facts of the grounds of which their claims are based, and to propose evidence confirming such facts. ${ }^{9}$

According to Article 2 of the Macedonian Law on Litigation Procedure: "In a litigation procedure the court shall rule within the frames of the claims being filed in the procedure"10 This article is referring to the petition or the subject of the dispute. It can also be found in theory as ground of the claim. On the other hand, article 176 of the same law contains the following provision: "The court shall act upon the lawsuit even when the plaintiff has failed to state the legal basis of the petition, and if the plaintiff has stated the legal basis, the court shall not be bound thereto". This provision refers to a different institute in litigation law, which is the legal basis of the lawsuit. The grounds of a lawsuit and the legal basis of a lawsuit can often be displaced or confused in practice. The legal basis of a lawsuit is presented by the provisions upon which certain rights of the claimant are raised, having in mind the actual situation. The legal qualification of the legal basis is always determined by the court. (Cavdar \& Cavdar, Закон за парнична постапка со коментари, судска практика, примери за практична примена и предметен регистар [Law on Litigation with comments, court practice, templates for practical use and registry], 2016, стр. 352) There are theoretical views that the qualification of the petition is a strictly legal question that is the exclusive competence of the court because it is a matter of application of substantive law. This is interpreted in the following manner: the court will decide which provisions will be applicable regarding the grounds of the petition, the provisions for unjust enrichment or the provisions for civil liability (Pajtic, Radovanovic, \& Dudash, 2018, p. 612). However,

\footnotetext{
${ }^{9}$ The court shall also be authorized to confirm the facts not being stated by the parties, and to exhibit the evidence not being proposed by the parties, if the outcome of the contention and the substantiation results in the parties being headed towards disposing with claims they cannot dispose with, but it cannot base its decision on facts and evidence wherefore the parties have not been granted the possibility to declare themselves.

${ }^{10}$ Law on litigation procedure Official Gazette of Republic of Macedonia No. 7/2011.
} 
based on the consulted legal literature, as well as legal practice and court decisions, we cannot agree with the last theoretical opinion. It is not up to the court to decide if, in certain cases, the provisions for unjust enrichment or the provisions for civil liability are applicable. If a claim for unjust enrichment was filed, the court will decide if the prerequisites for the unjust enrichment are fulfilled or not and, based on the litigation, will accept or reject the claim. This claim does not depend on fault or breach of a duty by the party unjustly enriched. If a claim for damages has been filed, then the court will decide if the prerequisites for raising a claim for a certain type of liability are present or not and it will adopt a decision to accept or reject the lawsuit. But if, based on the evidence in the litigation, the court establishes that the prerequisites for the obligation (liability for damages or unjust enrichment) are not present, then the court's decision will be to reject the claim as unfounded or groundless. The court cannot decide outside the frame of the claim. ${ }^{11}$

For the purpose of this paper we analysed the practice of the Basic Court in Shtip, regarding claims for unjust enrichment and compensation of damages. During the research we came across a few court decisions rejecting claims for unjust enrichment as unfounded. ${ }^{12}$ Although, reading and analysing these decisions of the Basic Court in Shtip and the corresponding decisions of the Court of Appeal in Shtip for dismissal of the appeal as unfounded and confirmation of the verdict of first instance made it clear for us that there were grounds for claim for tort liability and compensation of damages, but the claims were misplaced in first place. In this paper we will present only two cases of misplaced claims where the overlap between unjust enrichment and damages had consequences in the legal practice. These cases are representative of the practical overlap. Our purpose is to analyse them in order to present that overlap between unjust enrichment and damages from litigation aspect in way that will enrich the differentiation already present in legislation and theory.

The first case study refers to Decision of the Basic Court in Shtip TS1 No.8/17 and Decision of the Court of Appeals in Shtip TSZ-294/18 that confirms the verdict of the Basic Court. The ground of the claim is unjust enrichment, and the claimant claims that he and the defendant had a contract. The defendant was obligated to construct an enlargement of the claimant's storage place. The claimant paid in advance the total amount that he was obligated to pay to the defendant, which was 1,600,000 denars. But the defendant did not comply with his performance duties by the given deadline and the claimant made an additional contract with a different contractor to finish the construction work.

${ }^{11}$ Article 2, Law on Litigation Procedure.

12 Basic Court in Shtip TS1 No. 8/17, Court of Appeal in Shtip TSZ 294/18, Basic Court in Shtip TS1No. 4/16, Court of Appeal in Shtip TSZ 199/18, Basic Court in Shtip No. TS1 No. 33/16, Court of Appeal TSZ - 273/18. 
The claimant had an expert in the area of construction make an assessment of the total cost of finished construction work by the defendant. According to that assessment the amount was 1,188,637 denars. The claimant claimed the amount of the remaining 411,363 denars based on unjust enrichment by the defendant. That is why the court conducted the litigation procedure in the frames of this claim. That meant that the court had the task to establish if the prerequisites for unjust enrichment are fulfilled in this case. If there was an increase of the defendant's assets, decrease of the claimant's assets, correlation between the increase and decrease of assets and absence of legal basis for such actual situation. "During the determination of the facts that are of significance for deciding in the legal matter, the court has determined that in this case the legal prerequisites for the existence of unjust enrichment are not fulfilled, and this is because, from all the exhibited evidence on the main contention, the court determined that in the presence of the orally concluded contract between the parties, based on which the claimant paid the defendant total amount of $1,600,000$ denars, and which contract has not been annulled or terminated, the obligation of the defendant to pay the amount of 411,363 denars on grounds of unjust enrichment does not exist because the legal base have not been suspended." 13 The Court of Appeals has determined that the appeal from the claimant is ungrounded as the basic court has applied correctly the substantive law and has confirmed the decision of the basic court with decision TSZ 294/18.

Understanding the factual situation presented in both court decisions, one can only conclude that this was a case of contractual liability and liability for damages raised from breach of the contract duty. Under Macedonia law, the creditor is entitled to compensation for ordinary damages or loss of earnings and to equitable non-pecuniary damages that, at the time of entering into a contract, were foreseen by the debtor as possible consequences of a breach of the contract, considering the facts as they were knew or should have known at the time. In the case of fraud or deliberate non-performance or non-performance due to gross negligence, the creditor shall have the right to request from the debtor compensation for the entire damages that were caused due to breach of the contract, regardless of the fact that the debtor did not know of the particular circumstances resulting in the damages caused. ${ }^{14}$ But the court did not determine the facts regarding the existence of the basis for liability and assessment of damages because the grounds of the claimant's claim were not liability for damages but unjust enrichment.

${ }^{13}$ Decision of the Basic Court in Shtip TS1 No.8/17, from 14.05.2018, p.6.

${ }^{14}$ Article 251 of the Macedonian Law on Obligations. 
The second case study refers to Decision of the Basic Court in Shtip TS1.No. 4/16 and Decision of the Court of Appeals in Shtip TSZ-199/18.

According to the claim in this case, the claimant states that the defendant knew that he was not the owner of the entire property, and yet he concluded lease contracts and gained assets based on the usage of someone else's property. The grounds of the claimant's claim are unjust enrichment. In this litigation procedure, the court determined the facts relevant for the existence of the grounds of the claim, prerequisites for unjust enrichment. But, it was determined that all (two) lease contracts were concluded in accordance with the law because, at the time of the conclusion, the defendant was the only owner of the property that was listed in the public register, and that these contracts were not annulled or terminated during the duration and realization of the obligation. That is why the court decided that the claim was ungrounded and for that reason it was rejected. The Court of Appeals confirmed the decision of the Basic Court, stating that the substantive law

\section{Liability questions}

In the Macedonian law, the special regulations pertaining to the legal profession are the Law on Advocacy, the Statute of the Bar Association of the Republic of North Macedonia and the Code of Professional Ethics of Attorneys, Attorney Associates and Attorney Trainees. (Ampovska, 2018). According to the Macedonian Law on Advocacy ${ }^{15}$ the legal assistance of the party is provided by the lawyer conscientiously and expertly, in accordance with the law, the Code of Bar Code of Ethics and other acts of the Chamber and he keeps in confidence what is entrusted to him. The civil liability of the lawyer for damages caused during the performance of his practice is introduced in Article 30 paragraph 1 of the Law on Advocacy, which states that lawyers are responsible for professional and conscientious performance of the legal duty and for preserving the reputation of the profession. Paragraph 2 of the same article further defines what is considered a serious violation of the legal duty and reputation of the profession. According to this provision, the following will be especially harmful:

- non-performance or obviously negligent performance of legal aid activities and performance of public authorizations,

- failure to act after authorization,

15 Official Gazette of R. Macedonia No. 59/2002, no.60/2006, no.29/2007, no.106/2008, no.135/2011, no.113/2012 and no.148/2015. 
- failure to take actions that the lawyer is obliged to take in the protection of the rights and interests of the party,

- violation of the duty of confidentiality.

In cases where the lawyer has misrepresented a claim on the bases of the factual situation provided by his client, it consider is to be a failure to take actions that the lawyer is obliged to take in the protection of the rights and interests of the party and in that manner a wrongful act on the part of the lawyer. This wrongful act is performed with fault on the part of the lawyer and is considered ordinary negligence where the standard of care demands that the professional act in compliance with the rule of his practice. In cases of professional liability, where the lawyer's liability is positioned, according to Macedonian legal theory, the performance of professional actions is evaluated based on objective criteria, and it is not required for the professional to acts in the best professional manner in his practice but to act accordingly the rules that regulate the profession. (Galev \& Anastasovska, 2008, p. 578) In order to even start a practice, there is a condition concerning the right to practice, provided by the law. These provisions dictate that lawyers must have a designated level of professional liability insurance. Lawyers are placed under the burden of entering contracts which contain express requirements set mainly by the insurer, although both general and specific legal provision in this area is applicable. In Macedonian law, the compulsory liability insurance for lawyers is also required by the Law for Advocacy in Article 37-a. "The lawyer is obligated to have a liability insurance contract for the damage caused to third party intentionally during the lawyer's practice. The contract for liability insurance for lawyers, members of a law firm and for lawyers working in that company, is contracted by the company." This obligation also applies to a foreign lawyer and law firm. In this way, the damaged person, irrespective of the solvency of the lawyer, is reimbursed for the damages caused to him by intention or gross negligence, up to the amount of the insured sum with the insurance company and at the same time strengthens the confidence in the advocacy and improves the independence and autonomy of the advocacy as a public service for legal assistance. (Ampovska, 2018, p. 378)

The question of whether clients are familiar with the regulations for the professional liability of the attorney as well as the existence of the compulsory insurance of professional liability was not part of this research, and we cannot speak of the legal practice with regard professional liability, and especially liability of the attorney in case of misplaced claim for unjust enrichment or damages. This section was presented in order to draw attention to this question and to emphasise the importance and the legal consequences in case this occurs in practice. 
Conclusions

The research conducted for the purpose of this paper has brought us to the conclusion that Macedonian legislation as well as comparative legal theory offer clear basis and criteria for the differentiation of unjust enrichment and damages. The prerequisites for raising a claim for each of the two obligations are clearly drawn in the Macedonian Law on Obligations, as well as in the Macedonian legal theory. Although the overlap of fields between the two obligations are clearly noted in the comparative legal theory, it also offers a certain number of criteria for the differentiation. As we elaborated in the text, this overlap can be overcome using these principles:

- The principle of additional (supplemental) nature of the unjust enrichment that is manifested in raising a claim for this obligation, mainly when the prerequisites for the other obligations, liability for damages and negotiorum gestio, are not present in a specific case.

- The principle of competition which means that the compensation in any case is achievable only on the ground of one claim and accumulation of the two claims for one case is not allowed

- The principle of transition from liability for unjust enrichment to liability for damages

- The principle of combining the two obligations, in specific cases, in order to achieve full compensation

But it is also our conclusion that legal literature regarding the overlap between unjust enrichment and torts, for example handbooks and commentaries that are currently available to law practitioners in Macedonia are very poor in number and content, as the used relevant domestic literature shows.

Furthermore, we consider this as an area of high importance regarding the role of attorneys, as it is crucial for protecting subjective rights. The research showed that the qualifications and knowledge of the attorney to submit the proper claim in a specific case are crucial for the plaintiff to receive adequate legal protection. In case the claim is poorly presented and a claim for enrichment is given instead of a claim for damages or vice versa, the judge, under Macedonian civil litigation law, is obligated to reject the claim due to the principle "Ne eat iudex ultra petita partium". These cases have consequences for the plaintiff, as he has multiple expenses that were not necessary and faces the statute of limitations and possibility that his subjective right will be left without legal protection. 
The provided analyse of the legal practice and especially the presented case studies lead us to the conclusion that attorneys lack knowledge of the differentiation between these crucial institutes:

- deferring the legal basis from basis or grounds of the claim and

- deferring prerequisites for unjust enrichment and for liability for damages.

The consequences are:

- Litigation expenses for the parties that were unnecessary

- Engagement of the courts

- Statute of limitation for the claim for damages, as the prescription period of three or five years will easily expire during the litigation procedure for the ungrounded claim

- New expenses in money, human resources and time for the right claim to be addressed to the court

- Eventually raising the question concerning the attorneys' civil liability for the damage suffered on the part of the party because of raising the ungrounded claims.

Popularization of the overlap between unjust enrichment and damages through publication of research that offers scientific elaborations and analysis with regard overlap and differing the two obligations, as well as analysis of court practice and case studies that show negative practical (litigation effects of the mentioned overlap, are just one step towards better protection of rights in the area of civil law. 


\section{References $^{16}$}

Ampovska, M. (2018). Lawer's professional liability insurance in Macedonian Law. Universally and particulary at law (pp. 377-395). Kosovska Mitrovica: Universit in Prishtina.

Ampovska, M. (2020). Отитетно право [Tort law]. Shtip: Goce Delchev University.

Antic, O. (2009). Облигациионо право [Law of Obligations]. Beograd.

Cavdar, K., \& Cavdar, K. (2008). Закон за облигациионте односи, коментари, објаснувања, практика и предметен регистар [Law on Obligations, commentary, explanations, practice and subject registry],. Skopje: Agency Akademik.

Cavdar, K., \& Cavdar, K. (2016). Закон за парнична постапка со коментари, судска практика, примери за практична примена и предметен регистар [Law on Litigation with comments, court practice, templates for practical use and registry]. Skopje: Agency Akademik.

Galev, G., \& Anastasovska, J. D. (2008). Облигациионо nраво [Law of Obligations]. Skopje: CEPPE.

Jansen, N. (2010). The concept of Non-Contractual Obligations: Rethinking the Divisions of Tort, Unjust Enrichment, and Contract Law. Journal of European Tort Law, 1(1), 16-47.

Klarić, P. (2003). Odstetno pravo [Tort law]. Zagreb: Public journal.

Koziol, H. (2012). Basic questions of tort law from a germanic perspective. Wien: Jan Sramek Verlag.

Pajtic, B., Radovanovic, S., \& Dudash, A. (2018). Облигационо право [Law of Obligations]. Novi Sad: Faculty of Law in Novi Sad.

Radisic, J. (2018). Облигащчионо право општи део [Law of Obligations, general part]. Nis: Faculty of Law in Nis.

${ }^{16}$ The translation in English language of the references is made by the author. 
Smith, S. A. (2008, November 6). Unjust enrichment: Nearer to tort than contract. Oxford: Oxford University Press

Weinrib, E. (2016). Corrective Justice. Oxford University Press.

Zimmermann, R. (1995). Unjustified Enrichment: The Modern Civilian Approach. Oxford Journal of Legal Studies, Volume 15, Issue 3, 403429.

Jaksic, A. (2009). Грађанско прочесно право [Civil Litigation Law]. Belgrad: Official Gazzette.

\section{Legislation and court practice}

Law on Advocacy "Official Gazette of R. Macedonia" No. 59/2002, no.60/2006, no.29/2007, no.106/2008, no.135/2011, no.113/2012 and no.148/2015;

Law on Litigation Procedure "Official Gazette of R. Macedonia" No. 7/2011;

Law on Obligations "Official Gazette of R. Macedonia" No. 18/2001, 04/2002, 05/2003, 84/2008, 81/2009, 161/2009, 23/2013, 123/2013.

Legal (court) practice

Decision of the Basic Court in Shtip No. TS1 No. 33/16;

Decision of the Basic Court in Shtip TS1 No. 8/17;

Decision of the Basic Court in Shtip TS1. No. 4/1;

Decision of the Court of Appeals in Shtip TSZ 294/18;

Decision of the Court of Appeals in Shtip TSZ - 273/18;

Decision of the Court of Appeals in Shtip TSZ-199/18. 
